\title{
Positioning LGBTIQ as the human sexuality agenda for black theology of liberation - Reflection on Vuyani Vellem's black theology of liberation
}

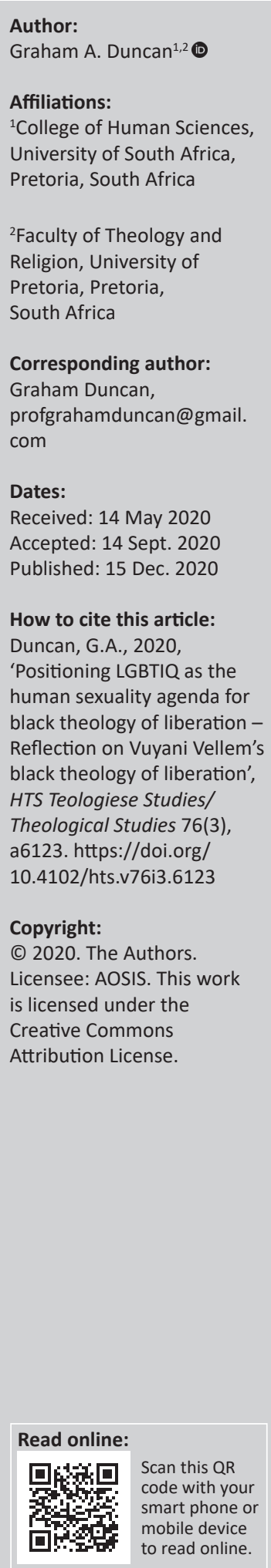

Vuyani Vellem was an outstanding Black Theologian of Liberation (BTL), who was approaching the zenith of his career when he died at the age of 50 years in 2019. This paper begins with a personal memoir to Prof. Vellem and a recognition that there is a lacuna in BTL relative to human sexuality issues. The contemporary global context of the human sexuality debate is discussed before the task of BTL in Vellem's thinking is outlined. This is followed by an examination of the situation in Africa and South Africa. Following this, the article proceeds to introduce the issue of human sexuality as a potential field of research in BTL and argues that the subject of human sexuality in the black community is a valid and appropriate topic for study and research by BTL.

Contribution: This article raises pertinent issues regarding the development of a Black Theology of Liberation (BTL) which includes a proposal for the inclusion of LGBTI+ issues. It seeks to expand the understanding of the oppressed to include those who are oppressed as the result of gender issues.

Keywords: black theology of liberation; homophobia; human sexuality; LGBTI; oppression; Vuyani Vellem.

\section{Memoir}

I first met Vuyani Vellem in 1997 at Alice when he was studying for his Master's degree in Theology at the University of Fort Hare. He had previously studied at the Federal Theological Seminary of Southern Africa (FEDSEM) where he had his first encounter with Black Theology (Vellem 2012:268) under Dr Cecil Ngcokovane. I returned to live and work in South Africa in 1998, and we picked up our friendship in the midst of him having a negative experience with the award of his Master's degree, which led to the degree MSocSc being conferred by the University of Cape Town.

Within the Reformed Presbyterian Church in Southern Africa (RPCSA), Vuyani served as the Junior Clerk of the final General Assembly (RPCSA 1999:1) in his first year in ministry. He had served his probation in the Northern Transvaal in Venda (1992-1994); thereafter, he was appointed to the Presbytery of the Western Cape (RPCSA 1997:86) at GG Ndzotyana Congregation, Khayamandi, Stellenbosch, from 1998 to 2002 (RPCSA 1999:12). I visited him there and he was proud to show me his manse which was, in his words, a 'shack' - mokhukhu (Vellem 201b:2-3,2017:1), just like the homes of his members. For Vellem, mokhukhu enacted the internal logic (Vellem 2014b) of African history, the agency of black Africans, the originality and moral consciousness (Vellem 2014:3). It was a source of liberating resources for life and consciousness in an existential sense (Vellem 2014:5). At the same time, he was the Director of Naval Chaplaincy and Lecturer in world ideologies in the South African National Defence Force (SANDF). In 2002, he moved to the Newcastle as minister (Vellem 2020:1).

He was by far the youngest member of the Special Commission on Union (RPCSA 1998:72), representing the RPCSA, which brought the Uniting Presbyterian Church in Southern Africa (UPCSA) into being in 1999. He was also appointed the RPCSA facilitator for the sub-commission on Signs and Symbols whose work would culminate in the lengthy disputes in the formation of the joint associations following the union (RPCSA 1998:149).

Note: Special Collection entitled VukaniBantuTsohangBatho - Spirituality of Black Liberation, sub-edited by Fundiswa Kobo (UNISA) and Rothney Tshaka (UNISA). 
I was Moderator of the General Assembly of the UPCSA in 2003, when Vuyani was elected the first black General Secretary of the denomination, and I was privileged to induct him into that office. We worked together, and got along well, respecting each other's roles and supporting one another. Vuyani's time at the General Assembly office was not easy and many of his proposals for reform were challenged and put on hold until he left and a non-white was appointed in his place. This was significant in a church where the majority of the membership is black. He was replaced by a minister of Asian descent who had left the Presbyterian Black Leadership Consultation, the black caucus of the Presbyterian Church in Southern Africa (PCSA). Racism leaves a filthy aftertaste. As the PCSA had not resolved its racial situation, so it also failed to resolve its diverse attitudes towards human sexuality and that remains true of the UPCSA.

During my moderatorial year (2004-2005), I was appointed to attend the ACCRA meeting of the World Alliance of Reformed Churches (WARC). Vuyani was frustrated when the WARC could not find funds to invite him. I decided to ask him to represent me so that he could attend. Little did I imagine the effect this would have on his academic and ecclesiastical or ecumenical development! The ACCRA Confession was the major outcome of this conference and provided a solid base for his ongoing reflections on 'empire' (cf. Vellem 2010b:101-111).

I sat on the panel that examined his $\mathrm{PhD}$ and was on the appointment panel when he was appointed to the Faculty of Theology at Pretoria University and later the Director of the Centre for Public Theology. We were friends and colleagues both in church and academia. We often lamented the lack of progress in our church, particularly with regard to the persistence of racism. He always reminded me: 'Graham, this is our church!'

Vuyani Vellem was an outstanding Black Theology of Liberation (BTL) scholar who was approaching the zenith of his career when he died at the age of 50 years in 2019. His death reminded me of how little we really knew of him. He has rightly been lauded as an excellent academic, but so little has been said about his role as a churchman. He described himself 'as a pastor, manager, ecclesiastical bureaucrat, researcher and teacher' (Vellem 2017:1). I would argue that it was because he was such a committed churchman that he became an outstanding academic and teacher of the BTL. Yet, he extended his academic reach to engaging constantly with church ministers. Soli Deo Gloria!

\section{Introduction}

Some time before his passing, the author and his colleague, the senior minister at St Andrew's Church, Pretoria of the UPCSA, Rev Zwai Mtyhobile, were engaged in a discussion with Vuyani Vellem on BTL. Vuyani had preached at St Andrew's on a number of occasions and was somewhat surprised to learn that St Andrew's is a gay-friendly congregation in which gay couples had been married in a liturgical service. His response was, 'Oh, Zwai, Graham, what have you done?' His shock was compounded when he became aware that he had met and engaged with one of the couples on more than one occasion. Again, 'Oh, Zwai, Graham, what have you done?' Vuyani never revealed his thoughts on the issue of human sexuality related to BTL. He certainly did not speak about it, nor did he reflect on it critically as a topic worthy of his attention in BTL at that stage in his career. Perhaps, it was only a matter of time before he did ... Regardless, this is a matter that requires attention in $\mathrm{BTL}$, as it is an issue whatever our personal convictions and prejudices are. However, this needs to be done taking the global context into account.

\section{The contemporary global situation}

Brian Stanley (2019:268) has described two significant issues relating to human rights discourse that emerged towards the close of the 20th century: it became more closely aligned with the Left in political terms and it began to move from the civil to the personal domain. Part of this was because of the situation where ' $[t]$ he predominant cultures in the Western world ... were more radically subjective in character than their predecessors. ... Such subjectivity was most controversially expressed in the area of human sexuality'. This was threatening for traditional ethical teaching expressed by the churches. Churches of the North had a historical influence on the younger churches that they reproduced, although these churches adopted a more conservative stance on matters of sexual identity (Stanley 2019:270). This caused disruption on a global level as these churches were all part of worldwide Christian communities.

However, as Stanley (2019:278) points out, 'There is ample historical evidence that homosexual practice, and (less frequently) long term homosexual relationships, have been features of many human societies down the centuries'. Further, he reminds us of the recent emergence of the term 'homosexuality' in 1868 by Karoly Maria Kertbeny. Whilst homosexuality may have existed, 'there was no concept of fixed homosexual orientation or identity' (Stanley 2019:278). Miranda Hassett (2007:243) comments that 'African Christians' responses to homosexuality are not dictated by northerners, but reflect African contexts and concerns'. This statement needs to be interrogated and challenged. Here we have a comment that applies more to churches that have their origin in the non-developed world, including Africa. Davies (2011:280) notes that 'gay theology' inter alia provides a challenge to those who continue to oppress and exploit constituencies like women, blacks and gays.

In the global discussion, it is generally true that 'the retention of homosexuality prohibitions was a matter of fundamental principle on which the holiness and spiritual integrity of their churches in their national contexts depended' (Stanley 2019:285):

... it became increasingly clear that the clash between the invocation of human rights and the appeal to unchanging Christian conceptions of divinely revealed truth touched ... on 
the ecclesiological issues of church leadership ... but, ... on theological anthropology - the Christian understanding of human identity. (p. 365)

This became an imported standard in South Africa and poses a challenge to the ongoing development of a BTL. We will proceed by examining Vellem's concept of BTL.

\section{The task of Black Theology of Liberation}

As the starting point of BTL is the black people who are oppressed, the social analysis of the context and condition of blackness are key to this paradigm. (Vellem 2017:4)

The matter of who or what is black became somewhat confused when Mokgethi Motlhabi suggested the integration of Black and African theologies (Motlhabi 2008). ${ }^{1}$ Vellem (2010a) responded:

Since the debate between Black and African Theologies which ultimately shows that both schools are not exclusive to each other, I have preferred to use the phrase 'black African' to demonstrate that our approach ... does not regard them to be exclusive, one against the other. The phrase 'black African' is used to show that there is no fundamental distinction we need to make between liberation and inculturation. I am also aware of the recent development in South Africa where Africans are now distinguished from the so-called coloured people and Indians, which groups were designated as blacks within the school of Black Theology of Liberation. The phrase 'black African' should not be treated as an attempt to distinguish blacks from other groups that we understand to be black, but rather as an inclusive phrase for the methodological approach that perceives Black and African theologies as 'soul mates'. (p. 314)

Naudé (2010:72) reverts to the Alliance of Black Reformed Christians in South Africa's (ABRECSA) inclusive definition of blackness formulated in the early 1980s, where being black is not a matter of skin colour, but it is represented by oppression. Vellem argues that human dignity (isidima) is founded in God's creation (Vellem 2010a:315), and constitutes the notion of a relationship, particularly in the black African context: 'considering them human just as human as we are - even if appearance suggests nonhumanity' (Vellem 2010a:316). This concept of nonhumanity was one source of oppression where 'Western Christianity became part of the historical disruption of the moral and ethical dispensation of life amongst black Africans' (Vellem 2014:1). Hence:

[T]he struggle for liberation in the context of South Africa was a struggle for dignity against the original denial of black Africans in history. The original denial of blacks in the discourse of dignity implies that they were not seen as an end, but rather as a means to the desires, rationality and epistemological aspirations of their oppressors. For centuries blacks have not been seen as a selfconscious people free to make their own decisions and express

1.'... one vividly remembers even one of the exponents of the school at the University of Cape Town in 1999 publicly declaring the death of BTL in one of the biggest international conferences I witnessed as a student then, the Multi-Event 1999' (Vellem, interview with Laubscher [2018:2]). their history and culture without any intimidation. ... For this reason, our view of the idea of dignity from the perspective of African culture is a process of rediscovering black African people's dignity. (Vellem 2010a:317)

Vellem affirmed unequivocally, "'Blackness" is not employed as a biological, or anthropological construct without necessarily denying ontological Blackness, but an existential term' (Vellem, interview with Laubscher 2018:2). It defines something much deeper than skin colour: 'Pigmentocracy is lock, stock and barrel a product of colonization and conquest with its marking of Black bodies as dispensable' (Vellem, interview with Laubscher 2018:8). This is related to the concept and practice of Ubuntu, which has ethical, religious, political and cultural implications with regard to human dignity:

Ubuntu is the capacity in African culture to express compassion, reciprocity, dignity, harmony and humanity in the interests of building and maintaining community with justice and mutual caring. (Vellem 2010a:319)

The antithesis of ubuntu is victimization, vengeance, and violence. (Vellem 2010a:318)

This is an area in which great sensitivity needs to be exercised considering the existential damage that has been perpetrated during the period of apartheid. This damage continues to be prevalent in terms of racism and other forms of discrimination such as in the area of human sexuality and experienced by the lesbian, gay, bisexual, transgender or intersex (LGBTI) community, who in terms of BTL may be considered to be the new 'poor' and, without doubt, one group amongst the oppressed. This community has hitherto not considered human sexuality to have been of significant importance for Vellem and other theologians of BTL. However, Maluleke is correct when he commented in personal correspondence with the author (Maluleke to Duncan, 04 April 2020):

... please do not single out black theology as if it was a big issue in any other theology. Global, white theology was no better in those years - human sexuality was not a big issue.

This is true, although it does not preclude us from raising it as a relevant issue for consideration and action in BTL. ${ }^{2}$ Maluleke has also been in the forefront of those asserting the continuing role of BTL in face of the ongoing issues that brought it into being under apartheid:

Today, the struggle for dignity, in the midst of poverty and hunger, is located in the 'primary power' of the poor. This is what seems to have been lost in the past fifteen years of democracy in South Africa. Furthermore, there are public issues that immediately require a discourse shaded by the vital force of isidima. Health, HIV/AIDS and unemployment are an ongoing agenda for black Africans, who are committed to the rediscovery of the dignity of their public discourse. The connectivity of life, a convivial 'shade' comprising God, faith, people, work, climate and land, all point to one thing, that isidima is relational to all of life.

2.The only works I was able to identify in this regard are Germond and De Gruchy (1997) [a collection of essays with no black authors] and Nicolson (2008), both somewhat dated in this regard; Couper in Kaunda and Hewitt (2018). 
One cannot conclude without pointing to the self-hate and anger that Africans have unleashed against themselves. West (1995:23) calls this a 'psychotic' disease of self-hate which is truly an expression of an inferiority complex engendered among Africans for many centuries. It is thus important to affirm the linguistic and the symbolic for life in public discourse. (Vellem 2010a:320)

Consistent with this Vellem (2017) determined the aim of BTL to be the restoration of:

$[T]$ he sanity, dignity and subjectivity of black Africans and the global South. (Vellem 2017:2) ... [It is a] quest for justice within an undeniable repugnant history of genocides, epistemicides and spiritualicides in the encounter between Africa and the West. (p. 2)

\section{His vision of BTL is:}

[C]ognitive and spiritual commitment to a justificatory logic of faith to break from the West and to move into another form of trust, trust in a new justificatory criterion for the promise of love and hope. (Vellem 2017:7)

Vellem challenges the assumption of civilisations who fail to affirm the full humanity of black people and yet seek to restore creation which is in a life and death struggle and whose dignity and right to life is constantly being undermined (Vellem 2017:3). He indicates that conversion or transformation is a sine qua non for the recognition of the human dignity of all people:

Such a conversion is paramount for 'rehumanisation', i.e. dignification of both black and white people. (p. 5)

We need to remember that the religiosity of Western Christianity equals cultural subjugation of the black Africans who were colonised. Black theology of liberation and its relationship with Black Consciousness should be understood in this way, particularly the psychosocial dimension of this school. (Vellem 2014:3)

The question that rises is, can BTL deal with the homophobia of black people against their own who are LGBTI?

Nothing could be crueller spiritually so, than a way of knowing that suppresses and defends guilt because white people know that they are guilty at least as beneficiaries of the systems that kept black people as underdogs. (Vellem 2017:5)

Does this statement apply equally to blacks whose very identity is challenged because they belong to the LGBTI community? Vellem (2017:7) talks about the erosion of identity in black people without mentioning this group specifically.

When questioned specifically regarding sexuality: 'How concerned is BTL with gender and sexual injustices in our society? Is it one of its current blind spots or not?' (Vellem, interview with Laubscher [2018:8]), Vellem responded that this is 'Possibly and arguably correct' (Laubscher 2018:8), and 'One cannot simply abstract one aspect in responding to coloniality' (Vellem, interview with Laubscher [2018:8]):
There could be reasons for some tardiness which saw emphasis rather on other aspects of liberation. However, BTL espouses a comprehensive notion of liberation and one would fully accept that this intensity is not only needed for our times, but urgently so. (p. 10)

He did not deny the validity of considering matters of human sexuality, but also did not consider it a priority. In his defence, Vellem commented:

I have been cautious about what I designate as innovative haste in theological thought and chose to be rather slow in discontinuing with BTL by consistently engaging its strong thought with some of its intensification in the process. (Laubscher 2018:13)

Yet, this is an urgent matter for those who suffer from the dehumanisation of homophobia, even within the church. In his defence, Vellem, whilst not mentioning human sexuality specifically, did refer to the need for a 'comprehensive notion of liberation': 'I have come that they might have life, and may have it in all its fullness' (Jn 10:10).

The image of the church as an agent of freedom can be a powerful ecclesiological symbol according to Holder-Rich (2001:93), who defines an agent as someone who brings about change. She concludes that 'work that leads toward freedom for people within the church, for families, for communities and for societies - is part of the call of Christians'. Bevans and Schroeder (2004:383) advocate a process they call a 'dialogue of life' and a 'dialogue of action', which lead to 'prophetic dialogue which enables us to communicate with people who do not share our convictions as we attempt to resolve issues which threaten our future communal life'. This can facilitate our sharing our faith in a hospitable context.

Vellem argued that Sen's Capability Theory is helpful in pointing to the eradication of the obstacles that hinder the comprehensive liberation of the marginalised. Sen argues that development is freedom, and his thesis provides a link in the tension and debates that have been propounded between development and liberation. The removal of un-freedoms resonates with the break with the systems of dependencies as suggested by the liberation paradigm we have already identified (Vellem 2016:5).

According to Vat Til, Sen thoroughly critiques mainstream economics (2008:85-88). Sen proposes a different standard for measuring economic success compared to that of mainstream economics, namely 'basic capabilities': By basic capabilities, Sen means 'the ability to do valuable acts or reach valuable states of being'. Sen's focus is the capability of humans to function freely. A person is an agent, and the agent must be able to act. Sen puts it his way:

This 'agency aspect' takes a wider view of the person [than merely 'well-being'], including valuing the various things he or she would want to see happen, and the ability to form such objectives and have them realized. (Vat Til 2008:85) 
It also goes beyond relegation to the domain of economics and is relevant to the issue of human sexuality globally and in Africa.

\section{Human sexuality issues in Africa}

There is a sense of denial in Africa regarding the existence of any other forms of human sexuality than heterosexuality. Homosexuality is perceived as a Western concept that was imported into Africa manifested, inter alia, by expressions of homophobia. ${ }^{3}$ The gospel has often been colonised by western interests through their support (funding) manifested by US bishops and African 'converts' to conservative evangelicalism (cf. 1998 Lambeth Conference and bribery of African bishops by their American counterparts [see Hassett 2007:71-101]):

[T]he idea that homosexuality is 'western' is based on another western import - Christianity. True African culture celebrates diversity and promotes acceptance. ...

One factor is the increased popularity of fundamental[ist] Christianity, by way of American televangelists, since the 1980s. While Africans argued that homosexuality was a western import, they in turn used a western religion as the basis for their argument. When I have challenged people who are antigay, many have said that it is not our culture. However, when you probe further, they argue that homosexuality is not in the Bible. But the Bible is not our historical culture. This shows there is real confusion about Africa's past. (Alimi 2015; cf Van Heerden 2018)

Here, the bible is used as a double-edged sword - to blame it for the presence of homosexuality and to use it against homosexuals. Antonio (1997:310) takes this further than simple co-option of scripture by confronting the duplicity of the churches' attitude towards traditional culture: 'Many of them still think of it (in terms of the old missionary ideology) as pagan and superstitious'. Yet, ironically, it is this culture which is invoked to combat homosexuality.

Van Heerden (2018) claims that historical evidence challenges the idea that lesbian, gay, bisexual and transgender (LGBT) people are alien to African culture. He cites recent history in Tanzania, where recent intensified efforts to suppress its gay community indicate the risk of statements by Africa's political, business and social elites, who seek to normalise hatred and discriminate against sexual minorities:

Many factors contribute to the marginalisation of the LGBTQ community, but categorising same-sex attraction as a foreign concept and a form of neo-colonialism has proven to be a powerful tool in oppressing this vulnerable group.

Homosexuality was commonplace among unmarried Tutsi and Hutu men in Rwanda, while lesbian relationships were common among the Nandi of Kenya, and basically universal among

3. ... the fear, hatred, discomfort with, or mistrust of people who are lesbian, gay or bisexual. Homophobia can take many different forms, including negative attitudes

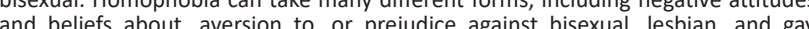
and beliefs about, aversion to, or prejudice against bisexual, lesbian, and gay people. It is often based in irrational fear and misunderstanding. Some people's homophobia may be rooted in conservative religious beliefs. People may hold homophobic beliefs if they were taught them by parents and families. Some LGBTQ people experience discrimination based on their sexual orientation or gende identity. This may be discrimination from religious institutions, companies or from our government (Planned Parenthood 2020). unmarried Akan women of Ghana. In the Langi tribe of northern Uganda, people who were born intersex or who were regarded as impotent would be labelled as a third gender known as mudoko dako. Mudoko dako people were legally and socially allowed to marry a man or woman and acquired either traditional male or female roles.

The idea of homosexuality is also a powerful political weapon in a number of African nations in the fight against historic western dominance, through the deprivation of dignity physical, moral, psychological and emotional.

The Africa Bible Commentary (Adeyemo 2006), authored by Evangelical African scholars, states that ' $[t]$ he Bible clearly defines homosexuality as a sin' (Turaki 2006:1355). However, it also notes that homosexual behaviour has had a varied history in Africa 'in all societies'. To appreciate the predominant African position, it is important to realise that homosexuality is against the law in most African states (Nkosi \& Masson 2017:78) (which is a vote winner for national leaders) and that the responsibility to marry and have children is a very strong expectation, supported by traditional African and biblical world views (Gn 1:28; 9:7). It is also the case that there are passages in the New Testament, especially Romans 1:24-7, that are clearly understood as condemnations of homosexual practice and orientation. For people who see the Bible as normative, the message seems plain. It is true that there is a clear disregard of scientific and cultural considerations, not to mention the experience of homosexual people - including many African Christians (Brown 2006). However, if there is to be reconciliation on the issue, one of the conditions must be that other Christians make a case on the basis of what is written in the Bible (Kim \& Kim 2016:110). However, Alimi (2015:1) confirms Van Heerden's (2018) assertion and clearly states that:

In digging up facts I found that, while many Africans say that homosexuality is un-African, African culture is no stranger to homosexual behaviours and acts.

For example, in my local language (Yoruba), the word for 'homosexual' is adofuro, a colloquialism for someone who has anal sex. It might sound insulting and derogatory, however, the point is there is a word for the behaviour. Moreover, this is not a new word; it is as old as the Yoruba culture itself.

In the northern part of Nigeria, yan daudu is a Hausa term to describe effeminate men who are considered to be wives to men. While the Yoruba word might be more about behaviour than identity, this Hausa term is more about identity. You have to look and act like a yan daudu to be called one. It is not an identity you can just carry. These words are neutral; they are not infused with hate or disgust.

Alimi's point relates to both behaviour and identity in some African cultures. Further, if there is a name for homosexuality, it must exist. Otherwise why have a name for something that does not exist? Then, 'one set of assumptions cannot be extrapolated to the general African context simpliciter without interrogating the underlying presumptions (prejudices?) even within the Christian community' (Alimi 2015:1). The 
predominant presumption here is that homosexuality is a Western imposition on an otherwise heterosexual continent. Finally, the neutrality of these terms indicates that these cultures do not judge on the basis of homophobia.

The matter of lawfulness in relation to scripture is problematic. Do we return to the practice of slavery, normalised in scripture but outlawed in the 19th century, to be revamped as human trafficking in the 20th century? It appears that only homophobia, one root of the homosexuality debate, escapes interrogation and condemnation, which is not extended to other prohibited activities such as eating pork and shellfish (Lv 11:7; 11:10). Consequently, we need to ask why we fixate on only one aspect of the Holiness Code? Is there a gradation of prohibitions that makes some more worthy of curses than others? Can we even venture to say that any sexual activity, so long as it occurs between members of different genders, is less obscene than same-sex activity? Further, the few texts from both the Old and New Testaments against what are considered homosexual practices are notoriously difficult to interpret (Römer 2018:215-228). A localised code of conduct (the Holiness Code in the Book of Leviticus) given to guide people in a crisis (e.g. the Exodus, Babylonian exile) is globalised as a one-size-fits-all ethical code. Even today we cannot simply extrapolate scripture from its context.

\section{Human sexuality issues in South Africa}

Reid (1997) cites an example of the African nature of homosexuality:

Thandekiso prefers the word injonga. Injonga is an African word that serves to undermine the notion that homosexuality is a western import, by claiming a specifically African import, by claiming a specifically African homosexual identity. (p. 114)

"Injonga is a gendered term that refers to the "male" identified partner in a male homosexual relationship' (Reid 1997:117 n.2). The situation is further complicated by the denial of the existence of intimate male relationships (Corbett 1997:170).

An anomalous situation exists in South Africa, where there is a contrast between the attitudes of white people who emphasise a greater degree of individualism, and possibly tolerance, contrasted with the collective identity of black communities (Stuart 1997:97). There is also a sharp contrast between its written policies and people's lived experiences, despite its leading the way in legislating marriage equality and legal protection against discrimination: 'In theory, SA is paradise for LGBTI people, says a global report, adding that in practice the picture is far less rosy' (Farber 2019:1). South Africa was the first nation in the world to protect against discrimination based on sexual orientation (Pillay 2018:1). However, because legal provision came before:

$[P]$ ublic acceptance, nationwide consensus or a massive shift in the social perception of LGBTQ+ people, this made South Africa an anomaly among many countries fighting for marriage equality. Legal protection preceded public acceptance. This is one of the reasons why we struggle with misconceptions and discrimination. ... [and] the deep-seated tendency towards the marginalisation of gay people in South Africa. (p. 2)

Pillay makes a good point because legal ratification normally follows a change in attitude or behaviour. However, here an ethical judgment was influential in policy formation. This is confirmed by a 2013 poll (The Pew Research Centre 2013), which noted that South Africa has lower rates of acceptance of homosexuality than all the other countries who have legalised same-sex marriage, but higher acceptance rates than any other African country. Briefly, there was a significant discrepancy between theory and practice. Yet:

The South African experience on LGBTIQ issues is therefore important, due to its unique positioning, situated within a historically complex set of intersectional oppressions of race, colonialism and gender that have been, at least partially, shaped by religion. (Palm 2019:3)

Pillay (2018) comments further that the gay issue is not openly discussed because of unrepresentative community leadership, which tends to sidestep this controversial issue:

Progressive Prudes, which conducted one of the first surveys on 'attitudes towards homosexuality and gender non-conformity in South Africa', noted that $51 \%$ believe that gay people should have the same human rights, but a staggering $72 \%$ feel that same-sex activity is morally wrong. The data regarding these perceptions is in line with the data regarding the lived experiences of LGBTQ+ people throughout the country. Fortyfour percent of the queer community reportedly experience verbal, physical and/or sexual discrimination in their everyday lives due to their sexual orientation, and sensitive issues are often remarkably under-reported. (p. 3)

This research reflects an ecclesiastical approach, which indicates that 'being' gay is one thing, but 'doing' gay is quite another matter; compare this with 'being' heterosexual and 'doing' heterosexual. One of the findings of Palm's (2019:iv) research stipulated a need to '[a]void a "double talk," where LGBTIQ orientation is accepted but not LGBTIQ practice. An ethos of radical inclusion nurtures full belong [sic], acceptance and celebration':

The report, State-Sponsored Homophobia published by the International Lesbian, Gay, Bisexual, Trans and Intersex Association named South Africa as 'undoubtedly a regional leader' with regard to marriage equality, constitutional rights and legal protection from discrimination for LGBTI people. Yet, 'SA's high rates of rape and homophobic crime, perpetrated disproportionately against lesbians of colour in poorer townships, demonstrate that robust legislation does not necessarily translate to societal acceptance'. (Farber 2019:1)

Sadly, this treatment is not limited to adults, but has infiltrated the educational system. McArthur (2015) writes about homophobic violence in a Northern Cape school:

The extent of homophobia and homophobic violence in the school leaves many boys [and girls?] vulnerable. They feel alone 
and isolated, to the extent that they are frequently absent from school. When asked about their experiences of homophobia and homophobic violence, I could hear anger as well as a deep sense of sadness. (p. 4)

McArthur (2015) concludes that there is a clear sense of unhappiness and frustration, which is linked to the workings of an oppressive system active at the school in which a culture of violence thrives where young gay persons have 'experienced harassment, inflicted by peers teachers and school administrators, avoidance, rejection, and isolation' (Francis 2017:5).

Wells and Polders (2006) also reported on victimisation and homophobia experienced in schools. Their findings highlight the fact that victimisation on the basis of sexual orientation was widespread and included verbal and physical abuse including rape. Similarly, a study by the Human Rights Watch (2011) provides empirical evidence that schools perpetuated and reinforced social prejudices and discrimination towards LGBT learners. This is continued in higher education. Nkosi and Masson (2016) found in their research among black South African students that:

$[P]$ articipants experienced the church as a very unwelcoming environment and fellow Christians as extremely judgemental. Feelings of rejection and of isolation were reinforced by people and a system that participants felt should have been supportive. (p. 72)

Waidzunas (2015:171) explains that often Christian gays live painful lives in the 'toxic closet', as a result of the fear of condemnation. South Africans support keeping the current constitutional protections against discrimination on the grounds of sexual orientation at a ratio of 2:1, compared to those who think it should be taken out. Since 2012, there has been a tenfold increase of South Africans who 'strongly agree' with allowing same-sex marriage - from 1 in a hundred, then to 1 in 10 now. The proportion of people 'strongly disagreeing' dropped from almost half (48.5\%) to less than a quarter $(23.4 \%)$ in the same period (Sutherland 2016:4). On this topic, with regard to ecclesiastical responses, Palm (2019) demonstrates that:

Evidence shows that many churches, and their religious beliefs, play a role in stigma faced by the LGBTIQ community and hold considerable authority at grassroots level within the African continent. They are uniquely positioned as part of the challenge of exclusion, but also form potential spaces where communities of belonging can be nurtured. (p. iv)

Palm (2019:13) has confirmed that many gays suffer from experiences of outright theological rejection. Yet, others 'noted a more complex harmful theology through the approach of many churches to say, "we love you BUT ..." reiterating a theology where they feel God says "I love you but you are rubbish" by "accepting" or tolerating LGBTIQ orientation'. However, this is 'not its embodied practice, by embracing only the single celibate individual but not the whole person in the midst of their concrete loving relationships'.

In one church, the UPCSA, a substantial report was presented to the General Assembly in 2016 with a strong focus on justice. It was based on a minority submission (referred to as MS2004 in the report) of the Presbytery of the Western Cape to the South African Law Reform Commission in 2004 (UPCSA 2016:389-399). One issue that is dealt with is the injustice dealt out to homosexuals on the basis of their sexual orientation. It reports on Archbishop Desmond Tutu's assertion that churches have demonstrated prejudice against homosexuals causing substantial psychological damage, and this is supported by Dr Fritz Gaum (Gaum \& Gaum 2010:29):

Gay people are still the object of twisted jokes, jeering looks and talk behind their backs. That must wound - 'and the hurt goes very deep'. (p. 29)

Desmond Tutu highlighted the essential injustice as early as 1996, when he spoke out against the injustice perpetrated by Christians who shared a common baptism. As author of the Forward in a book by Bennett and Preston (1996), he lamented:

It is a 'cri de coeur' from the hearts of persons we have first accepted as baptized fellow Christians, members together with us all in the body of this Jesus Christ, wherein as a result of that baptism there is neither Jew nor Greek, male nor female, free nor slave - there is a radical equality....

... we spurn them, we shun them, because we are all caught up in an acknowledged or a tacit homophobia and heterosexism. We reject them, treat them as pariahs, and push them outside the confines of our church communities, and thereby we negate the consequences of their baptism and ours.

We make them doubt that they are the children of God, and this must be nearly the ultimate blasphemy. We blame them for something that it is becoming increasingly clear they can do little about. (Tutu 1996:ix)

The injustices of church treatment of homosexuals are problematic in a democratic society.

Further, the 2016 UPCSA report highlighted the South African term 'corrective rape', resulting in physical attack, rape and murder. David Russell (2004:30) has added his critique that the church has been responsible for cruel and inhuman treatment of homosexuals. The report MS2004 (in UPCSA 2016) stated the command to love people of every kind:

... historically the Church's stand on human rights has often been poor. Its general attitude to homosexual people in particular, and its treatment of them, has fallen appallingly short of Jesus' fundamental command to love people of every kind. ... The tragically much higher incidence of suicide among homosexuals has been blamed on continuing social hostility, and the attitude of the Church and Christians has often been at the root of this: the rejection and hostility in western society as a whole is largely rooted in the Christian tradition. Many homosexuals have as a result turned their 
backs on the Church. In many cities, like Cape Town [and Pretoria], homosexual Christians have felt it necessary to start their own churches. (p. 389)

In addition, it is not possible to evaluate the damage done to families of gay children whose parents have been faithful and committed members of churches who reject their children, through leaving the church in solidarity with their offspring, or by causing family division. Bosman (2009:1) explains that because of negative reactions many gay Christians may move out from their home churches because of the churches' discriminatory beliefs about homosexuality and find a new spiritual home. This clearly exemplifies the degree of injustice experienced not only by families but also by their loved ones. It is acknowledged that more recently, some denominations have begun to recognise the levels of human angst experienced and have begun to change their attitudes with regard to significant scriptural passages 'in the light of God's Word of love and grace that became incarnate in Jesus Christ' (UPCSA 2016:390). This has been reflected in theological scholarship both within South Africa (e.g. eds. Germond \& De Gruchy 1997; Judge, Manion \& De Waal 2008; Russell 2004) and beyond. Palm (2019:1) pointed to the strong influence ministers of religion exercise amongst their congregants as they:

$[H]$ old considerable power and authority and influence their constituency's beliefs and behaviours (Le Roux \& Bartelink 2017:23). They are often key role-players informalising and celebrating major life events such as births, deaths and marriages. Thus, they are uniquely positioned in relation to shaping community attitudes regarding sexuality, relationships and understandings of family and parenting.

The negative framing of the LGBTIQ debate in many churches (are 'we' going to let 'them' in) needs to be challenged at its roots for a positive framing of belonging together that celebrates creational diversity as an invitation to all to listen, learn and change. (p. 34)

Davis (2013) referred to Tutu's stress on the potential of religious leaders and the need to equip them to think differently about interpretation of their sacred texts. This relates negatively to the low academic attainment of many ministers, particularly in African Initiated Churches (AICs), where theological education is a low priority and, therefore, there is little understanding of biblical hermeneutic, especially with regard to the so-called 'terror texts' (Gn 19:5, Jd 19.22, Lv 18:22, 20:13, Rm 1:24-27, 1 Cor 6:9, 1 Tim 1:10). If lesbian, gay, bisexual, transgender, intersex and questioning (LGBTIQ) acceptance in South Africa is to grow, he notes that religious leaders have a key role to play in challenging a 'religiously sanctioned homophobia which maintains an "us and them" dichotomy' (Gunda 2017). This arises out of homosexuals being cast in the role of the 'enemy' who is a threat to the stability of the family, the church and society at large, even in the absence of evidence to the contrary. What exacerbates the situation is the denial of Jesus' command 'Love your enemies' (Lk 6:27). The enemy is a common human commodity in BTL.

\section{Human sexuality as an appropriate topic for a Black Theology of Liberation}

As has been stated earlier, BTL is a dynamic field of study, which has undergone change in emphasis. In an earlier phase, it was lamented that it avoided gender issues by remaining:

... silent on the oppression of black women. In its opposition to oppressive structures of the church, Black Theology does not include among such structures patriarchalism. The lesson is very clear for black women: the liberation of black women is the responsibility of black women. (Mosala 1986:129)

This indicates the need for an activist theology with praxis at its heart. There is a systemic bias against women who form the majority of church members who must wrest their liberation by their own efforts. Kobo (2019:91) refers even today to ' $[t]$ he tendency of BTL to speak of the black community as if black women do not exist'. She cites Cone (1979):

... whatever the reason for our silence on the unique oppression of Black women, we now must realise that our continued silence can only serve to alienate us further from our sisters. We have no choice but to take a public stance for or against their liberation. (p. 363)

With regard to the South African context, Kobo (2019:92) refers to a discussion with Alan Boesak on this matter in which he conceded that, 'had BTL included women from the beginning, the liberation of black humanity would have been a success'.

Further, this is not a class, but an economic, issue in which the church is complicit:

The class-transcending oppression ... must be situated within its proper context, namely, bourgeois culture which develops from and feeds into capitalist social relations of production, exchange and distribution. (Bennett 1986:169)

From this, it becomes clear that, historically, black women were oppressed and had to struggle for their liberation. So too, now, the same case can be stated for the liberation of black LGBTI persons. This is not a localised problem as is evident from the attention that South African churches have given to the matter.

It is worth noting at this point that the issue of human sexuality was exercising the mind of all of the mainline denominations in South Africa and globally at this time (UPCSA 2004:221):

This specific issue is receiving significant global attention at this time, even seen as at risk of fracturing the worldwide church and has been problematically portrayed at times using an African/ Western static binary. The South African experience on LGBTIQ issues is therefore important, due to its unique positioning, situated within a historically complex set of intersectional oppressions of race, colonialism and gender that have been, at least partially, shaped by religion. (Palm 2019:3) 
One denomination which has paid specific attention to the human sexuality debate is the United Reformed Church of Southern Africa (URCSA), the majority of whose members are black. The matter had been under consideration from the early 2000s, and a substantive report was submitted to the General Synod in 2008. Whilst the report acknowledged the traditional conservative approach to scripture, the members of the commission who drew up the report (all of whom are recognised South African theologians, two of whom are professors Allan Boesak and Rothney Tshaka, well-known black theologians) focused on a more open hermeneutic approach to scripture taking account of the recent research. Whilst the report was rejected, it nonetheless made a strong contribution to the debate from a BTL perspective. The black theological perspective became clear from the beginning of the report:

For the Bible it is the personhood of the victim that matters, and the fact that that personhood is rooted in the image of God. An assault upon any person in whatever form is an assault upon the image of God ....

The focus is on the victims. Challenging traditional conservative interpretations, the report stated clearly:

Others however, hold the equally strong opinion that these texts are not a condemnation of the homosexual orientation as we understand that today, but rather a rejection of specific, perverse forms of homosexuality, for instance rape, temple prostitution, idolatry and pederasty. (URCSA 2008a:70)

Following the logic of this hermeneutic and applying it to the New Testament texts (Rm 1, 1 Cor 6 and 1 Tim 1), the report argues that injustice visited upon the vulnerable in society is idolatry as far as it raises cultural norms to the level of God's law.

Yet, with specific reference to Romans 1:18-31, Dale Martin (2006:51-64) offers an interpretation which is more clearly aligned to Paul's first-century Graeco-Roman context than modern Christian heterosexism. He focuses on the cultural and ideological context of scripture. He delineates what he describes as 'cultural homophobia' (Martin 2006:61). Martin (2006:52) views Romans 1 as the construction of idolatry and its results rather than the fall of humanity. Referring to the lack of a concept of homosexuality, he suggests that this was not an issue of misplaced desire, but of 'legitimate desires that were allowed illegitimate freedom' (Martin 2006:58). As he extends his argument, he concludes that modern approaches amount to 'a classic case of homophobia' (Martin 2006:61), with the acknowledgement that ' $[h]$ omosexual desire lurks within us all. The fear of its outbreak motivates the current interpretive politics of homosexism' (Martin 2006:64). This conclusion is both provocative and compelling.

\section{Yet, the URCSA report concentrates on:}

Paul's emphasis in Romans is on justice, the doing of justice, which would nudge the believers of today in our context and with our cultural perceptions, towards the promotion of lesbigay or trans-rights as a matter of social justice. (URCSA 2008b:96)
This led the report to the question:

Should the church in its care and concern for the marginalised, in its attempts to promote justice on earth, and to counter discrimination and violence against those on the periphery of society, not actively engage the LGBT-communities of faith and include them with the same boldness that Jesus invited all to the Kingdom of heaven, with a particular invitation issued to the marginalised of society? (URCSA 2008b:99)

The report concluded from an investigation of the biblical evidence:

On basis of the full biblical evidence, both Old Testament and New Testament, and when considering the texts most often used in the lesbigay-debate as well as other important relevant texts, we conclude that there is a strong enough rationale to argue that on basis of the Bible a homosexual orientation should be acknowledged as part of God's created cosmos with all its diversity. (p. 101)

The report then turned to its confessional statement, the Belhar Confession, with its emphasis on 'justice, unity, reconciliation; the integrity of the Gospel, the faith of the church and the Lordship of Jesus Christ' (URCSA 2008b:104) for support, and concluded that:

Belhar, more than any other document perhaps, confirms that identity [i.e. Oneness in Jesus Christ]. That is true. We see it even stronger: Belhar was not just a defining moment, it is a defining presence for us. (p. 102)

The main focus here is on 'humanbeingness' in community, which is a gift to all:

It is: unbreakable and untouchable by any human law or cultural or personal prejudice. ... It is within this context also that Belhar calls upon us to remember that 'we are obligated to give ourselves willingly and joyfully to be of benefit and blessing to one another (since) we share the one faith ...' As true as this is of our racial relations, it is true of our other human relationships as well, especially in the church. (URCSA 2008b:103)

The URCSA report (2008b) concluded that the situation in which homosexuals find themselves is one of injustice, where:

[i]n their woundedness, their vulnerability to the denial of their rights, the enmity of many in society and the church, and the rejection of their true and full humanity, homosexual persons have an inalienable right to call upon the God 'who in a special way (is) the God of the destitute, the poor and the wronged'. (p. 106)

The report sees a direct positive correlation between the plight of many homosexual people and the struggle in the cause for Black liberation (URCSA 2008b):

The reasons that are given for justifying homosexual people as somewhat sub-human are very similar .... The bible is used conveniently, as it was during the black liberation struggle as a gun that shoots at this people. (pp. 115-116)

The recommendations that were consistent with the report emphasise a BTL perspective:

That moreover the evidence of Scripture is overwhelmingly in favour of hospitality to those who are traditionally not welcomed, 
acceptance of those who are stigmatised, rejected and alienated, compassion towards those who endure anxiety, suffering and humiliation because of their identity, and solidarity with those who are marginalised and oppressed, justice to those who are wronged - in this case homosexual persons;

That these principles constitute the heart of the ministry and Gospel of Jesus Christ as they are in equal measure found at the heart of the Confession of Belhar, and in this matter the church is once again called to 'stand where God stands';

That these considerations are essential to the unity of the church, the calling toward reconciliation placed upon the church by Jesus Christ, and the justice to which the church is obligated. (URCSA 2008b:131)

Following the rejection of the report, Boesak took a principled stand against the URCSA's decision. In an address, he argued that 'LGBTQI persons are made into aliens in their own land, strangers in the church, exiled from our love and consideration' (Boesak 2019:3), and that in the words of the Belhar Confession "'the church should stand where God stands": namely with the wronged, the poor, the destitute and powerless against the powerful; and against any form of injustice and oppression' (Boesak 2019:4). He challenged the view that was reminiscent of apartheid ideology, which alienated others as the result of 'enmity, distance, aversion, discrimination, degradation and domination'. That is, the 'diversity' as defined by the apartheid ideology, 'which becomes the cause for separation, inferiorization, and exclusion', as it 'eliminates dignity and the bond of humanity' (Boesak 2019:7):

The situation of the LGBTQI person is in its deepest reality a situation of injustice. ... In their woundedness, their vulnerability to the denial of their rights, the enmity of many in society and the church, and the rejection of their true and full humanity, LGBTQI persons have an inalienable right to call upon the God, ... Before God, there is no hierarchy of oppression and injustice. The injustice done to LGBTQI persons is no less an abomination than the injustice done to the black poor and powerless. With God, justice is indivisible, as love is indivisible, as God is indivisible. Therefore, with regards to gays, lesbians, bi-sexual, transgender, queer, and intersexual persons, as it is with the oppression and marginalization women, the challenge is the same: in their struggle for the recognition of their rights to full humanity, the church also must learn ... to witness and strive against 'any form of injustice', so that also for those members of the body of Christ 'justice may roll down like waters, and righteousness like an ever-flowing stream'. (p. 12)

Vuyani Vellem would have shouted a loud 'Amen' to this panegyric of Boesak. It is irrelevant against whom injustice is perpetrated. If it constitutes an infringement of the human rights and dignity of persons, it is injustice and is a contradiction of the plan of god who created all human beings:

\footnotetext{
... little less than God

crowning his head with glory and honour

You make him master over all that you have made,

putting everything in subjection under his feet ... (Ps 8:5-6)
}

\section{Conclusion and future prospect}

Professor Vuyani Vellem's life, ministry and academic research as a Black Theologian of Liberation (BTL) was devoted to the empowerment of the oppressed in society. Although he himself did not engage with the issue of human sexuality directly, his work laid the guidelines for restoring the full humanity of all persons created in God's image. In recent years, following the demise of legalised apartheid, many believed that BTL had run its course. Vellem and others have rejected this view by challenging its proponents to stand with the oppressed and reflect critically on their condition. Repealing laws does not necessarily result in attitudinal conversion or transformation, as we have seen with specific regard to issues relating to human sexuality. Perhaps, the emergence of this issue of human sexuality has served to help the Church to evade dealing with continuing issues of racism in South African society. As Maluleke (see note 3) has stated, BTL has not been alone in being remiss in engaging with this matter - western-based theologies have fared no better.

The radical nature of BTL requires that all that dehumanises be rejected and all that enhances life be promoted. Hence, the necessity of an ongoing onslaught against all that militates against the emergence of the existential well-being of all persons, including the oppressors. This requires the further development of an Ubuntu ethic, which focuses on human potentiality and is based on inclusivity, the promotion of human dignity, justice, liberation and all that contributes to harmony and reconciliation in society.

I believe the case has been made for BTL to take up the plight of those in society who are oppressed as a result of their sexual orientation as a matter of urgency. It is an issue that is legitimate, appropriate and part of our calling as Christians created in the image of God.

\section{Acknowledgements Competing interests}

The author has declared that no competing interest exists.

\section{Author's contributions}

The author is the sole contributor to this article.

\section{Ethical consideration}

This article followed all ethical standards for a research without direct contact with human or animal subjects.

\section{Funding information}

This research received no specific grant from any funding agency in the public, commercial or not-for-profit sectors.

\section{Data availability statement}

Data sharing is not applicable to this article as no new data were created or analysed during this study. 


\section{Disclaimer}

The views and opinions expressed in this article are those of the author and do not necessarily reflect the official policy or position of any affiliated agency of the author.

\section{References}

Adeyemo, T. (ed.), 2006, Africa Bible commentary, Zondervan, Nairobi.

Alimi, B., 2015, 'If you say being gay is not African, you don't know your history' viewed 17 June 2016, from https://www.theguardian.com/commentisfree/2015/ sep/09/being-gay.

Antonio, E.P., 1997, 'Homosexuality and African culture', in S. De Gruchy \& P. Germond (ed.). Aliens in the household of God: Homosexuality and Christian faith in South Africa, pp. 295-312, David Philip, Cape Town.

Bennett, B., 1986, 'A critique on the role of women in the Church', in I.J. Mosala \& B. Thagale (Eds.), The unquestionable right to be free: Essays in Black Theology, pp. 169-174, Skotaville, Johannesburg.

Bennett, M. \& Preston, J., 1996, We were baptized too: Claiming God's grace for lesbians and gays, Westminster, Louisville, KY.

Bevans, S.B. \& Schroeder, R.P., 2004, Constants in context: A theology of mission for today, Orbis, Maryknoll, New York, NY.

Boesak, A.A., 2019, 'Taking a stand - A call to action by the church against injustice towards LGBTI people', viewed 05 September 2020, from www.theother foundation.org.

Bosman, J., 2009, 'Re-interpreting the spiritual experience of gay men in the Pentecostal/Charismatic tradition', Practical Theology in South Africa 23(1), 1-18.

Brown, T., 2006, 'Introduction', in T. Brown (ed.), Other voices, other worlds, pp. 1-6, Darton, Longman \& Todd, London.

Cone, H.J., 1979, 'Black theology and black women: Introduction', in J.H. Cone \& G.S. Wilmore (eds.), Black theology: A documentary history, 1966-1979, Orbis Books, Maryknoll, New York, NY.

Corbett, I.D., 1997, 'Homosexuality in the traditions of the Church', in S. De Gruchy and P. Germond (ed.), in Aliens in the household of God: Homosexuality and Christian faith in South Africa, pp. 162-172, David Philip, Cape Town.

Davies, D.P., 2011, 'Who does theology', in D.E. Singh \& B.C. Farr (ed.), Christianity and education: Shaping Christian thinking in context, pp. 274-284, Regnum, Oxford.

Davis, R., 2013, 'Analysis: Why Tutu's support for gay rights matters', Daily Maverick, 29 July, viewed n.d., from https://www.dailymaverick.co.za/article/2013-07-29analysis-why-tutus-support-for-gay-rights-matters/

Farber, T., 2019, 'SA's homophobia report card: Great in theory, horrible in practice', viewed 20 April 2020, from https://www.timeslive.co.za/news/south-africa/201903-20-sas-homophobia-report-card-great-in-theory-horrible-in-practice/.

Francis, D.A., 2017, 'Homophobia and sexuality diversity in South African schools: A review', Journal of LGBT Youth 14(4), 359-379. https://doi.org/10.1080/ 19361653.2017.1326868

Gaum, F. \& Gaum, L., 2010, Praat verby grens, Interplay Books, Pietermaritzburg.

Germond, P. \& De Gruchy, S., 1997, Aliens in the household of God: Homosexuality and Christian faith in South Africa, David Philip, Johannesburg.

Gunda, M.R., 2017, Silent no longer! Narratives of engagement between LGBTI groups and the churches in southern Africa, Report: The Other Foundation, Kentucky, USA

Hassett, M.K., 2007, Anglican communion in crisis: How episcopal dissidents and their African allies are reshaping Anglicanism, Princeton University Press, Princeton, NJ.

Holder-Rich, C., 2001, 'Development as freedom or freedom as development? A Christian dialogue with Amartya Sen's development as freedom', Journal of Theology for Southern Africa 110 (July), 89-96.

Human Rights Watch, 2011, 'We'll show you you're a woman', in Violence and discrimination against Black lesbians and transgender men in South Africa, pp. 1-86, Human Rights Watch, New York, NY.

Judge, M., Manion, A. \& De Waal, S. (eds.), 2008, To have and to hold: The making of same-sex marriage in South Africa, Fanele (Jacana), Braamfontein.

Kaunda, C.J. \& Hewitt, R.R. (eds.), 2018, Who is an African?: Race, identity, and destiny in post-apartheid South Africa, Lexington Books, London.

Kim, S. \& Kim, K., 2016, Christianity as a world religion: An introduction, 2nd edn., Bloomsbury, London.

Kobo, F.A., 2019, 'Womanism and black anthropology: In memory of James Cone', Journal of Theology for Southern Africa 162 \& 163, 82-100.

Laubscher, M., 2018, 'Interview with Vuyani S Vellem', Acta Theologica 38(1), 1-14. https://doi.org/10.18820/23099089/actat.v38i1.1

Le Roux, E. \& Bartelink, B.E., 2017, No more 'harmful traditional practices': Working effectively with faith leaders, Research Report. Joint Learning Initiative for Faith Communities, Washington, DC.

McArthur, T., 2015, 'Homophobic violence in a Northern Cape school: Learners confront the issue', Agenda 29(3), 53-59. https://doi.org/10.1080/10130950.201 5.1056587

Maluleke, T.S., 2020, Letter to Duncan, 4 April.
Martin, D.B., 2006, Sex and the songle saviour: Gender and sexuality in biblical interpretation, Westminster John Knox Press, Louisville, KY.

Mosala, B.I., 1986, 'Black theology and the struggle of the black woman in south Africa', in I.J. Mosala \& B. Thagale (eds.), The unquestionable right to be free: Essays in black theology, pp. 129-133, Skotaville, Johannesburg.

Motlhabi, M., 2008, African theology/Black theology in South Africa: Looking back, moving on, UNISA Press, Pretoria.

Naudé, P.J., 2010, Neither calendar nor clock: Perspectives on the Belhar confessions, Eerdmans, Grand Rapids, MI.

Nicolson, R., 2008, The church and same-sex marriage, Cluster Publications, Pietermaritzburg.

Nkosi, S. \& Masson, F. 2016, 'Christianity and homosexuality: contradictory or complimentary? A qualitative study of the experiences of Christian homosexual university students', South African Journal of Higher Education 31(4), 72-93. http://dx.doi.org/10.20853/31-4-891

Nkosi, S. \& Masson, F., 2017, 'Christianity and homosexuality: Contradictory or complementary? A qualitative study of the experiences of Christian homosexual university students', South African Journal of Higher Education 31(4), 72-93. https://doi.org/10.20853/31-4-891

Palm, S., 2019, From exclusion to embrace: Re-imagining LGBTIQ presence in local church congregations, Unit for Religion and Development Research, University of Stellenbosch, Stellenbosch.

Pillay, R., 2018, South Africa still hasn't won LGBTQ+ equality. Here are 5 reasons why, World Economic Forum (WEF), November 28, viewed 20 April 2020, from https:// www.weforum.org/agenda/2018/11/south-africa-road-to-lgbtq-equality/.

Planned Parenthood, 2020, What is homophobia? viewed 2 April 2020, from https:// www.plannedparenthood.org/learn/sexual-orientation/sexual-orientation/whatwww.planned
homophobia.

Reformed Presbyterian Church in Southern Africa (RPCSA), 1997, Proceedings of the General Assembly, RPCSA, Umtata.

Reformed Presbyterian Church in Southern Africa (RPCSA), 1998, Proceedings of the General Assembly, RPCSA, Umtata.

Reformed Presbyterian Church in Southern Africa (RPCSA), 1999, Proceedings of the General Assembly, RPCSA, Umtata.

Reid, G., 1997, 'Coming home: Visions of healing in a Gauteng church', in De Gruchy \& P. Germond (ed.), Aliens in the household of god: Homosexuality and Christian faith in South Africa, pp. 101-119, David Philip, Cape Town.

Römer, T., 2018, 'Homosexuality in the Hebrew bible: Some thoughts on Leviticus 18 \& 20 and the David-Jonathan narrative', in M. Oeming (ed.). Avahah: Die liebe gottes im alten testament, pp. 215-228, Evangelische Verlagsanstalt, Leipzig.

Russell, D., 2004, The Bible and homosexuality: What is the spirit saying to the churches? CPSA, Cape Town.

Stanley, B., 2019, Christianity in the twentieth century, Princeton University Press, Princeton.

Stuart, D., 1997, 'Homosexual Christian communities in Gauteng', in S. De Gruchy \& P. Germond (ed.), Aliens in the household of god: Homosexuality and Christian faith in South Africa, pp. 178-187, David Philip, Cape Town.

Sutherland, C., 2016, Progressive prudes: A survey of attitudes towards homosexuality and gender on conformity in South Africa, The Other Foundation, Johannesburg.

The Pew Research Centre, 2013, The global divide on homosexuality: Greater acceptance in more secular and affluent countries, viewed 2 April 2020, from https://www. pewglobal.org/2013/06/04/the-global-divide-on-homosexuality.

Turaki, Y., 2006, 'Homosexuality', in T. Adeyemo (ed.), Africa Bible commentary, p. 1355 , Zondervan, Nairobi.

Tutu, D.M., 1996, 'Forward', in M.B. Alexander \& J. Preston (eds.), We were baptized too: Claiming god's grace for lesbians and gays, $\mathrm{pp}$. ix- $\mathrm{x}$, Westminster John Knox Press, Louisville, KY.

Uniting Presbyterian Church in Southern Africa (UPCSA), 2004, Papers and proceedings, UPCSA, Johannesburg.

Uniting Presbyterian Church in Southern Africa (UPCSA), 2016, Papers and proceedings, UPCSA, Johannesburg.

URCSA, 2008a, Minutes of the fifth general synod 2008, URCSA, Hammanskraal.

URCSA, 2008b, Fifth general synod of the uniting reformed church in Southern Africa: Agenda for Synod, URCSA, Hammanskraal.

Van Heerden, G., 2018, 'The west exported homophobia, not homosexuality', News 24, 2 December, viewed n.d., from https://www.news24.com/news24/Columnists/ GuestColumn/the-west-exported-homophobia-not-homosexuality-20181202

Vat Til, K., 2008, 'Human nature and human needs in recent economic theory', in D.A. Hicks \& M. Valeri (eds.), Global neighbors: Christian faith and moral obligation in today's economy, pp. 65-88, Wm. B. Eerdmans, Grand Rapids, MI.

Vellem, V.S., 2010b, 'On black South African public theology in a global era', Theologia Viatorum 34(1), 101-119.

Vellem, V.S., 2010a, 'Serithi/isidima: Reflections on human dignity in South Africa from a black African perspective', Scriptura 104, 314-321. https://doi. org/10.7833/104-0-173

Vellem, V.S., 2012, 'Allan Aubrey Boesak: A black public theologian from the belly of a Kgodumodumo', in P. Dibeela, P. Lenka-Bula \& V.S. Vellem (eds.), Prophet from the South: Essays in honour of Alan Aubrey Boesak, pp. 268-276, SUN Press, Stellenbosch.

Vellem, V.S., 2014b, 'Spirituality of liberation: A conversation with African religiosity', HTS Teologiese Studies/Theological Studies 70(1), Art. \#2752, 1-7. https://doi. org/10.410kgodumodumo2/hts.v70i1.2752 
Vellem, V.S., 2014a, 'The task of urban black public theology', HTS Teologiese Studies/ Theological Studies 70(3), Art. \#2728, 1-6. https://doi.org/10.4102/hts. v70i3.2728

Vellem, V.S., 2016, 'Imvuselelo: Embers of liberation in South Africa post-1994', HTS Teologiese Studies/Theological Studies 72(1), a3501. https://doi.org/10.4102/hts. v72i1.3501

Vellem, V.S., 2017, 'Un-thinking the West: The spirit of doing Black Theology of Liberation in decolonial times', HTS Teologiese Studies/Theological Studies 73(3), a4737. https://doi.org/10.4102/hts.v73i3.4737
Vellem V.V., 2020, 'A critical black analysis of the church's role in the post-apartheid struggle for socio-economic justice', Centre for Public Theology, Department of Dogmatics and Christian Ethics, University of Pretoria, Pretoria, South Africa.

Waidzunas, T., 2015, 'Reviews: Pray the gay away', American Sociological Association 44(2), 171-172. https://doi.org/10.1177/0094306115570271

Wells, H. \& Polders, L., 2006, 'Anti-gay hate crimes in South Africa: Prevalence, reporting practices, and experiences of the police', Agenda 67, 12-19.

West, C., 1995, 'Learning to talk of race', in L. Hord \& J.S. Lee (eds.), I am because we are, p. 23, University of Massachusetts, Amherst. 